\title{
Solar panel performance analysis under indonesian tropic climate using sandia PV array performance model and five parameter performance model
}

\author{
Subhan Petrana ${ }^{1}$, Eko Adhi Setiawan ${ }^{2, *}$, and Adi Januardi ${ }^{3}$ \\ ${ }^{1}$ Department of Electrical Engineering, Faculty of Engineering,Universitas Khairun, Ternate, Indonesia \\ ${ }^{2}$ Tropical Renewable Energy Centre, Faculty of Engineering, Universitas Indonesia, Depok, Indonesia \\ ${ }^{3}$ Department of Electrical Engineering, Faculty of Engineering, Universitas Indonesia, Depok, Indonesia
}

\begin{abstract}
Evaluation and monitoring of solar panel are need to be done, primarily related to how much energy is produced. Energy production by a solar panel is affected by the characteristics of climate or weather of a particular location such as solar radiation and ambient temperature. This study aimed to compare two models of solar panel performance calculation, i.e., Sandia PV Array Model and Five Parameter Model by considering the tropical climate of Indonesia and see the effect of temperature and solar radiation changes on the results of the calculations of both methods through the I-V curve. The types of solar panels on monitored are a monocrystalline, polycrystalline, and thin film. The results show that the energy produced by Sandia PV Array Performance Model for the three types of solar panels are 54.36 Wdc, $51.57 \mathrm{Wdc}$, and $39.62 \mathrm{Wdc}$, respectively. Five Parameter Performance Model results are $56.58 \mathrm{Wdc}, 52.7 \mathrm{Wdc}$, and 43.29, respectively. These results show that with a small amount of data, the Five Parameter Model is more optimal and efficient for the tropics compared to Sandia PV Array Model.
\end{abstract}

\section{Introduction}

Investments worth USD809 reported by Bloomberg for the construction of the power plant of the year 2010-2015 photovoltaic [1], Most of this investment was allocated for the purchase of solar panels that power the output values based on Standard Condition Test (STC) as radiation $1000 \mathrm{~W} / \mathrm{m} 2$, solar panel temperature $25 \mathrm{oC}$, wind speed $1 \mathrm{~m} / \mathrm{s}$ and Air Mass (AM) 1.5[2]. However, the advantage of this investment is not determined based on conditions of STC but rather determined by the energy produced by solar panels that are affected by environmental conditions [3]. The performance of a solar panel is rated based on the energy produced, reliability, and efficiency of its conversion [4], [5].

The production of energy by solar panels through the process of converting solar energy into electricity depends heavily on climate or environmental parameters of a particular region [2], [6], those parameters are solar radiation intensity, solar panel temperature, wind speed and humidity [7]-[9]. Solar panel performance testing studies are mostly conducted in sub-tropical regions, so the results do not necessarily represent the general tropical conditions, including Indonesia. Tropical environments have distinctive characteristics [7]-[10] :

1. Have a high-temperature range $18-40^{\circ} \mathrm{C}$ that can cause a rise in temperature of the solar panel reach $90^{\circ} \mathrm{C}$ so it can degrade the performance of the solar panel.
2. The high level of humidity, i.e., $35-85 \%$ with low wind speeds ranged from $0.2 \mathrm{~m} / \mathrm{s}$.

3. The trend of clouds and has high annual precipitation. This condition causes the low index of brightness that has an impact on the performance of solar panels.

With these characteristics, the solar panels operating in tropical regions need to be evaluated to determine how much energy is produced for the benefit of the investment due to the tropical climate leads to a significant deviation from STC conditions [2].

Some research on evaluation and testing the performance of solar panels associated with a tropical climate have been carried out by several researchers. In Nigeria which is a tropical country, conducted a study to investigate the influence of environmental temperature on the solar panel [11]. The result shows the presence of correlation between the temperature of the environment with the power generated by the solar panels. At low temperatures, the power generated is high but on the contrary with the high temperatures the generated power is low. Furthermore, research that evaluates the efficiency of the solar panel power conversion related dust, humidity and air speed [12] report, the power conversion efficiency decline in some tropical countries. In the U.S. that reaches $1-4.7 \%$ for two months, in Saudi Arabia in the amount of $32-40 \%$ in a month, the $17-65 \%$ 6-8 in Kuwait for 38 days, and a decrease of $33.5-65.8 \%$ for six months in Egypt, and in Thailand reached $11 \%$.

\footnotetext{
* Corresponding author: ekoas@eng.ui.ac.id
} 
In Sinegal, Ababacar Ndiaye, et al [13] evaluates the degradation of short circuit current $\left(\mathrm{I}_{\mathrm{sc}}\right)$ and open-circuit voltage (Voc) associated with power. The results shown in the period of 10 years there is a decrease in $\mathrm{I}_{\mathrm{sc}}$ and Voc respectively by $13 \%$ and $11 \%$. Furthermore, research was done in Singapore by Timothy M. Walsh et al [14] against commercial solar panels of various types, the results showed that some solar panels have a less good performance in Singapore's tropical climate.

The primary focus of the research is to compare two models calculation of the solar panels performance, i.e., Sandia PV Array Performance Model (SPAPM) and Five Parameters Performance Model (FPPM). These methods are chosen because in its calculation SPAPM method uses the results of climatology data processing directly to determine the value of solar panel output at its operating conditions, whereas in the FPPM method, the working principle of solar panels is modeled into a single diode equivalent circuit. The analysis of this circuit will yield five parameter values ie $a, I_{L}, I_{o}, R_{s}, R_{s h}$. These five parameters are components of a single diode equivalent circuit used to determine the value of solar panel output.

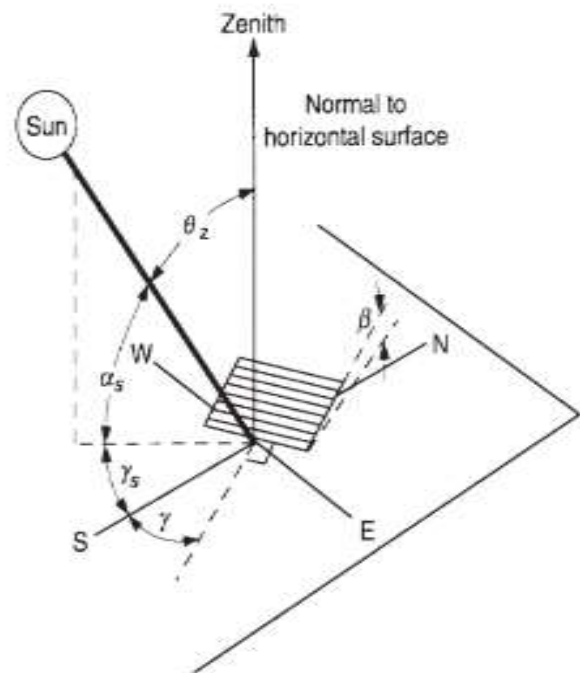

(a)

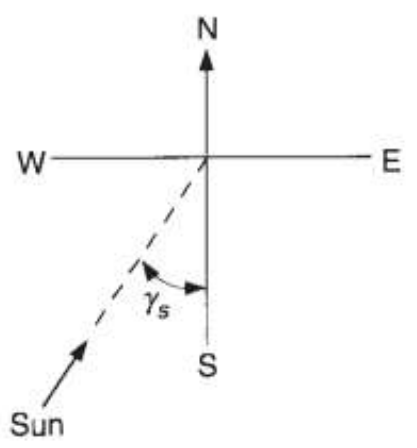

(b)

Fig. 1. (a) Zenith angle, slope, surface azimuth angle and solar azimuth angle for a tilted surface ; (b) Plan view showing solar azimuth angle [15]

\section{Solar Radiation}

The distance between the center of the earth and the sun is estimated as far as $1.495 \times 10^{11} \mathrm{~m}$, and solar radiation reaches the Earth's surface through a process called radiation. Solar radiation outside the Earth's atmosphere is called the solar constant $\left(\mathrm{G}_{\mathrm{sc}}\right)$ of $1.367 \mathrm{~W} / \mathrm{m}^{2}$ [15].

\subsection{The Geometric Solar Radiation to Earth's Surfaces}

The geometric relationship between the beam radiation and the earth's surface is shown in Fig.1[15]. $\beta$ is Slope Angel i.e. the angle between the surface plane and the horizontal plane $\left(0^{\circ} \leq \beta \geq 180^{\circ}\right)$. $\gamma$ is Surface Azimuth Angel i.e. the projection deviation on a horizontal plane from normal to the surface of the local meridian. While $\gamma_{\mathrm{s}}$ is solar azimuth angle that is the angular displacement from the southern beam radiation projection on the horizontal plane. Zenith angle $\left(\theta_{z}\right)$ is the angle between the vertical surface and the line to the sun, i.e. the angle of incident beam radiation on a horizontal surface. $\alpha_{s}$ or solar altitude angle is the angle between the horizontal surface and the line to the sun, or the complement angle of zenith.

\subsection{Solar Time}

Solar Time is the time of movement of the sun's angle visible in the sky with solar noon as the sun passes the observer's longitude or is the relative position of the sun to the observation point [15]. Solar time depends on the time of observation and the day of observation in a year [16].

$$
\begin{aligned}
& E o T=9.87 \sin 2 B-7.53 \cos B-1.5 \sin B \\
& B(\text { deg })=\frac{360^{\circ}}{365} x(d-81)
\end{aligned}
$$

Substitution of equation (2) into (1) then the obtained value of the EoT. Thus the solar time can be calculated using the equation:

$$
\begin{aligned}
& T_{\text {Solar }}=T_{\text {local }}+\frac{\text { EoT }}{60}+\frac{\text { Long }_{\text {sm }}-\text { long }_{\text {local }}}{15} \\
& \theta_{h r}=15^{\circ} \times\left(T_{\text {Solar }}-12\right)
\end{aligned}
$$

Equation 4 is the hour angle that is a representation of the solar time in the form of the value of the degrees from the movement of the sun at all times.

\subsection{Sun Declination}

Sun declination angle $(\delta)$ is the angle between the line of the equator the Earth with a straight line that connects the center of Earth to the center of the Sun. This angle determines the position of the Sun towards the Earth at a given day within a year. The angle of declination varies every season because of the tilt of the Earth on the axis of its rotation and the rotation of the earth around the Sun 
[17]. The magnitude of the angle of declination is calculated with the equation:

$\left.\delta=\sin ^{-1}(\sin 23.45) \sin \left(\frac{360}{365}(d-81)\right)\right)$

\subsection{Sun Elevation}

Sun elevation angle (h) is the height of the Sun in the sky angle measured from the horizontal line (ground level) or in other words the angle formed between the direction of the oncoming sunlight with the soil surface. The elevation angle is $0^{\circ}$ at the time of sunrise and sunset, and $90^{\circ}$ valued when the Sun is exactly above head [18]. The elevation angle is calculated using the equation:

$h=\sin ^{-1}\left(\sin \delta \sin \varphi+\cos \delta \cos \varphi \cos \theta_{h r}\right)$

Zenith angle $\left(\theta_{z}\right)$ is the complement of the angle of elevation or angle formed between the direction of the oncoming sunlight with a vertical line. The magnitude of the zenith angle:

$\theta_{z}=90^{\circ}-h$

or

$\theta_{z}=\cos ^{-1}\left(\sin \delta \sin \varphi+\cos \delta \cos \varphi \cos \theta_{h r}\right)$

\subsection{Sun Azimuth Angle}

Sun azimuth angle denoted by $\mu_{\mathrm{s}}$ is the direction of the compass from which sunlight comes. As in the compass direction the azimuth angle will be $0^{\circ}$ when the sun is to the north of the observation point and will be $180^{\circ}$ when the sun is on the south [19]. The azimuth angle is calculated by the equation:

$\mu_{s}=\sin ^{-1}\left(-\frac{\sin \theta_{h r} \cos \delta}{\cos \theta_{z}}\right)$

\subsection{Angle of Incidence}

Angle of Incidence (AOI) is the angle between the direction of the coming of the light from the Sun to the surface of the solar panel and the line normal to the surface of the solar panel. The value is determined by the angle of the AOI formation especially solar panel tilt angle (tilt angle) the effect on solar radiation absorbed by the solar panels. The greater the value of the AOI then solar radiation absorbed progressively reduced so that the output of solar panels to decrease. This happens when AOI worth $65^{\circ}$ or more [20]. The value of AOI is determined by the equation:

$A O I=\cos ^{-1}\left(\cos \theta_{z} \cos \beta+\sin \theta_{z} \sin \beta \cos \left(\mu_{s}-\mu\right)\right.$

\subsection{Beam Radiation}

Beam Radiation $\left(\mathrm{E}_{\mathrm{b}}\right)$ Beam Radiation $(\mathrm{Eb})$ is the solar radiation received directly without the occurrence of scattered by the earth's atmosphere [15]. Beam Radiation is the multiplication of Direct Normal Irradiance (DNI) with Angle of Incidence (AOI) written as [21]:
$E_{b}=D N I \cos \theta$

\subsection{Diffuse and Ground Reflected Radiation}

$E_{d}$ or diffuse radiation is solar radiation received after scattering occurs which is caused by the Earth's atmosphere so that the direction of the radiation is turned or deflected [15]. $E_{d}$ is calculated using equation [22] :

$E_{d}=D H I x \frac{1+\cos \beta}{2}$

While the ground reflected radiation $\left(\mathrm{E}_{\mathrm{g}}\right)$ that is leaning on the surface radiation reflected from the ground, and formulated as [23]

$E_{g}=$ DHI $x$ Albedo $x \frac{1-\cos \beta}{2}$

$G H I=D H I+D N I \cos \theta_{z}$

\subsection{Total Radiation (Plane of Array Irradiance)}

Total Radiation or Plane of Array Irradiance $\left(E_{p o a}\right)$ is the summation of the beam radiation, diffuse radiation and ground reflected radiation [24]. Written mathematically as :

$E_{P O A}=E_{b}+E_{d}+E_{g}$

\subsection{Air Mass}

Air Mass is the length of the path traversed by the light rays through the atmosphere normalized to the along the path with the shortest possible. Air mass quantifies the reduction in strength of the light when passing through the atmosphere and is absorbed by air and dust [25]. The air mass is calculated based on the equation:

$A M=\frac{1}{\cos \theta_{z}}$

The air mass is calculated based on the equation [26]:

$A M_{a}=A M e^{-0.0001184 h}$

Furthermore, to calculate the air mass in the form of a function of a polynomial of the air mass absolute or referred to as the air mass modifier $\left(\mathrm{M}_{\mathrm{AM}}\right)$ used equation [27]:

$M_{A M}=a_{o}+a_{1} A M_{a}+a_{2} A M_{a}^{2}+a_{3} A M_{a}^{3}+a_{4} A M_{a}^{4}$

Value of $a_{0}, a_{1}, a_{2}, a_{3}, a_{4}$ are the coefficient vektor whose value is determined while testing the solar panel.

\section{Methodology}

In this study, the selected location is Halim Perdanakusuma area in East Jakarta (-6.264451 N and 106.895859 E). Data required such as solar radiation climatology, environment temperature, air mass, albedo, 
and wind speed. The data obtained by use of the software of Meteonorm. As for the data is as follows:

Table 1. Climatology Data

\begin{tabular}{|l|c|}
\hline DNI $\left(\mathrm{W} / \mathrm{m}^{2}\right)$ & 95 \\
\hline $\mathrm{DHI}\left(\mathrm{W} / \mathrm{m}^{2}\right)$ & 422 \\
\hline $\mathrm{GHI}\left(\mathrm{W} / \mathrm{m}^{2}\right)$ & 516 \\
\hline $\mathrm{T}_{\mathrm{a}}\left(\mathrm{Dry}\right.$ Bulb) ${ }^{\circ} \mathrm{C}$ & 30.6 \\
\hline $\mathrm{W}_{\mathrm{s}}(\mathrm{m} / \mathrm{s})$ & 7.4 \\
\hline Longitude Standar Meridian $(\mathrm{deg})$ & 105 \\
\hline Local Longitude $(\mathrm{deg})$ & 106.9 \\
\hline Local Latitude $(\mathrm{deg})$ & -6.25 \\
\hline $\mathrm{E}_{\mathrm{o}}\left(\mathrm{W} / \mathrm{m}^{2}\right)$ & 1000 \\
\hline $\mathrm{T}_{\mathrm{o}}\left({ }^{\circ} \mathrm{C}\right)$ & 25 \\
\hline Albedo & 0.2 \\
\hline Day of Measurement & 296 \\
\hline Tilt $($ deg $)$ & 45 \\
\hline Elevation $(\mathrm{m})$ & 30 \\
\hline Azimuth $(\mathrm{deg})$ & 0 \\
\hline
\end{tabular}

On the research of this type of solar panel that evaluated i.e. polycrystalline, monocrystalline and thin film with specifications and data in a condition of STC as indicated in table 2 .

Table 2. Specification of Solar Panel (Sandia National Laboratory)

\begin{tabular}{|c|c|c|c|}
\hline Type of Cell & $\begin{array}{l}\text { Astropower } \\
\text { Apex Bin } \\
\text { G/APX-90 }\end{array}$ & $\begin{array}{l}\text { Siemens } \\
\text { Bin1/SP75 }\end{array}$ & $\begin{array}{c}\text { Solarex } \\
\text { Mega } \\
\text { Cell/MSX } \\
-64\end{array}$ \\
\hline \multicolumn{4}{|c|}{ At Reference Conditions } \\
\hline $\operatorname{Isc}_{0}(\mathrm{~A})$ & 5.11 & 4.37 & 4.25 \\
\hline $\operatorname{Imp} p_{0}(\mathrm{~A})$ & 4.49 & 3.96 & 3.82 \\
\hline $\operatorname{Voc}_{0}(\mathrm{~V})$ & 29.61 & 42.93 & 41.50 \\
\hline $\mathrm{Vmp}_{0}(\mathrm{~V})$ & 23.17 & 33.68 & 32.94 \\
\hline $\mathrm{a}_{0}$ & 0.938110 & 0.935823 & 0.918093 \\
\hline $\mathrm{a}_{1}$ & 0.062191 & 0.054289 & 0.086257 \\
\hline $\mathrm{a}_{2}$ & -0.015021 & -0.008677 & -0.02445 \\
\hline $\mathrm{a}_{3}$ & 0.001217 & 0.000527 & 0.002816 \\
\hline $\mathrm{a}_{4}$ & -0.000034 & -0.000011 & -0.00013 \\
\hline$\alpha \operatorname{Isc}\left(\% /{ }^{\circ} \mathrm{C}\right)$ & 0.000916 & 0.000401 & 0.000560 \\
\hline$\alpha \operatorname{Imp}\left(\% /{ }^{\circ} \mathrm{C}\right)$ & 0.000358 & -0.00039 & 0.000047 \\
\hline$\beta \operatorname{Voc}\left(\mathrm{V} /{ }^{\circ} \mathrm{C}\right)$ & -0.12995 & -0.15237 & -0.15280 \\
\hline$\beta \mathrm{Vmp}\left(\mathrm{V} /{ }^{\circ} \mathrm{C}\right)$ & -0.13039 & -0.15358 & -0.15912 \\
\hline $\mathrm{b}_{0}$ & 0.998980 & 1.000341 & 0.998515 \\
\hline $\mathrm{b}_{1}$ & -0.006098 & -0.005557 & -0.01212 \\
\hline $\mathrm{b}_{2}$ & 0.0008117 & 0.0006553 & 0.001440 \\
\hline $\mathrm{b}_{3}$ & -0.00003376 & -0.0000273 & -0.00005 \\
\hline $\mathrm{b}_{4}$ & $5.647 \mathrm{E}-07$ & $4.641 \mathrm{E}-07$ & $8.78 \mathrm{E}-07$ \\
\hline $\mathrm{b}_{5}$ & $-3.371 \mathrm{E}-09$ & $-2.806 \mathrm{E}-09$ & $-4.9 \mathrm{E}-09$ \\
\hline $\mathrm{c}_{0}$ & 0.9615 & 0.9995 & 1.0144 \\
\hline $\mathrm{c}_{1}$ & 0.0368 & 0.0026 & -0.0055 \\
\hline $\mathrm{c}_{2}$ & 0.2322 & -0.5385 & -0.3211 \\
\hline$c_{3}$ & -9.4295 & -21.4078 & -30.2010 \\
\hline $\mathrm{n}$ & 1.357 & 1.026 & 1.025 \\
\hline Ns & 56 & 72 & 72 \\
\hline$\varepsilon(\mathrm{eV})$ & 1.12 & 1.12 & 1.14 \\
\hline PV type & Poly & Mono & Thinfilm \\
\hline
\end{tabular}

The temperature of the solar panel is one of the parameters is calculated in this study based on equation [27]:

$T_{m}=E_{P O A} e^{\left(a+b \cdot W_{s}\right)}+T_{a}$
$T_{c}=T_{m}+\frac{E_{P O A}}{E_{0}} \Delta T$

The value a dan b on the equations (19) and (20) are parameters that depend on the material of construction, as well as the configuration of the installation of the solar panels specified [28] as shown in the table below:

Table 3. Parameters values various of module types and configurations

\begin{tabular}{|l|l|l|l|l|}
\hline Solar Panel Type & \multicolumn{1}{|c|}{ Mount } & \multicolumn{1}{|c|}{$\mathrm{a}$} & $\mathrm{B}$ & $\begin{array}{l}\Delta \mathrm{T} \\
\left({ }^{0} \mathrm{C}\right)\end{array}$ \\
\hline Glass/cell/glass & $\begin{array}{l}\text { Open } \\
\text { Rack }\end{array}$ & -3.47 & -0.0594 & 3 \\
\hline Glass/cell/glass & Close roof & -2.98 & -0.0471 & 1 \\
\hline $\begin{array}{l}\text { Glass/cell/polyme } \\
\text { r sheet }\end{array}$ & $\begin{array}{l}\text { Open } \\
\text { Rack }\end{array}$ & -3.56 & -0.0750 & 3 \\
\hline $\begin{array}{l}\text { Glass/cell/polyme } \\
\text { r sheet }\end{array}$ & $\begin{array}{l}\text { Insulated } \\
\text { Back }\end{array}$ & -2.81 & -0.0455 & 0 \\
\hline $\begin{array}{l}\text { Polymer/thinfilm/ } \\
\text { steel }\end{array}$ & $\begin{array}{l}\text { Open } \\
\text { Rack }\end{array}$ & -3.58 & -0.113 & 3 \\
\hline
\end{tabular}

\subsection{Performance Model for Solar Panel Modul}

\subsubsection{Sandia Photovoltaic Array Performance Model}

Sandia Photovoltaic Array Performance Model (SPAPM) is one of the solar panel performance calculation models developed by David L. King et al.[27] at Sandia National Laboratories. The basic equations used to describe the electrical performance of individual solar panels, but can also be used in array configurations. The equations used in this model are:

$$
\begin{aligned}
I_{S C}= & I_{S C_{0}} x f_{1}\left(\frac{E_{b} f_{2}+E_{d} f_{d}}{E_{0}}\right) x\left(1+\alpha_{I S C}\left(T_{c}-T_{0}\right)\right) \\
I_{m p}= & I_{m p_{0}}\left(C_{0} E_{e}+C_{1} E_{e}^{2}\right)\left(1+\alpha_{I m p}\left(T_{c}-T_{0}\right)\right) \\
V_{O C}= & V_{O C_{0}}+N_{S} \delta \ln \left(E_{e}\right)+\beta_{V O C}\left(T_{c}-T_{0}\right) \\
V_{m p}= & V_{m p_{0}}+C_{2} N_{s} \delta \ln \left(E_{e}\right)+C_{3} N_{s}\left\{\delta \ln \left(E_{e}\right)\right\}^{2}+ \\
& \beta_{V m p}\left(T_{c}-T_{0}\right) \\
P_{m p}= & I_{m p} V_{m p} \\
F F= & \frac{P_{m p}}{I_{S C} V_{O C}}
\end{aligned}
$$

Where,

$$
\begin{aligned}
& E_{e}=\frac{I_{S C}}{I_{S C_{0}}\left(1+\alpha_{I S C}\left(T_{C}-T_{0}\right)\right)} \\
& \delta=\frac{n \cdot k\left(T_{c}-273.15\right)}{q}
\end{aligned}
$$

To form a more precise I-V curve with this model two more equations are added when $\mathrm{Ix}$ is $\mathrm{V}=0.5 \mathrm{VOC}$ and Ixx when $\mathrm{V}=0.5(\mathrm{VOC}+\mathrm{Vmp})$, the equation is:

$I_{x}=I_{x_{0}}\left(C_{4} E_{e}+C_{5} E_{e}^{2}\right)\left(1+\alpha_{I s c}\left(T_{c}-T_{0}\right)\right)$

$I_{x x}=I_{x x_{0}}\left(C_{6} E_{e}+C_{7} E_{e}^{2}\right)\left(1+\alpha_{I m p}\left(T_{c}-T_{0}\right)\right)$ 


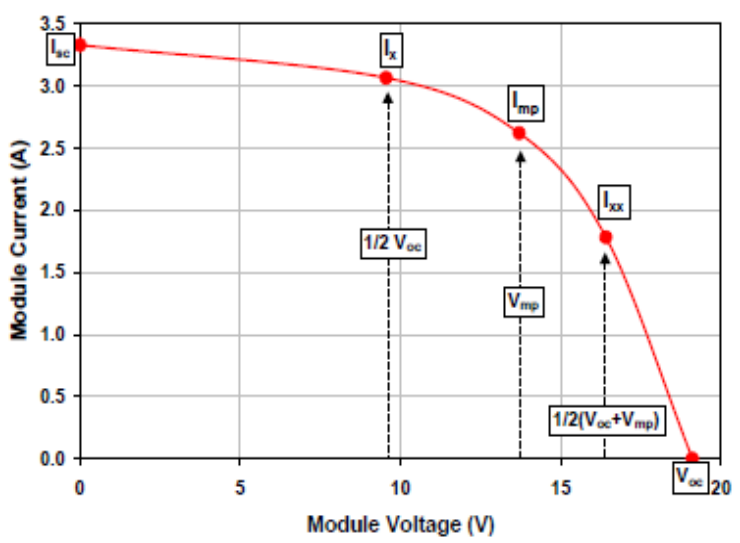

Fig. 2. Five point on I-V Curve in SPAPM

Equation 21-30 are used to calculate the amount of power and energy generated by solar panels under the assumption that the performance coefficients of solar panels are predetermined and solar data sources are available. The calculation process using the SPAPM model is shown in the flowchart below:

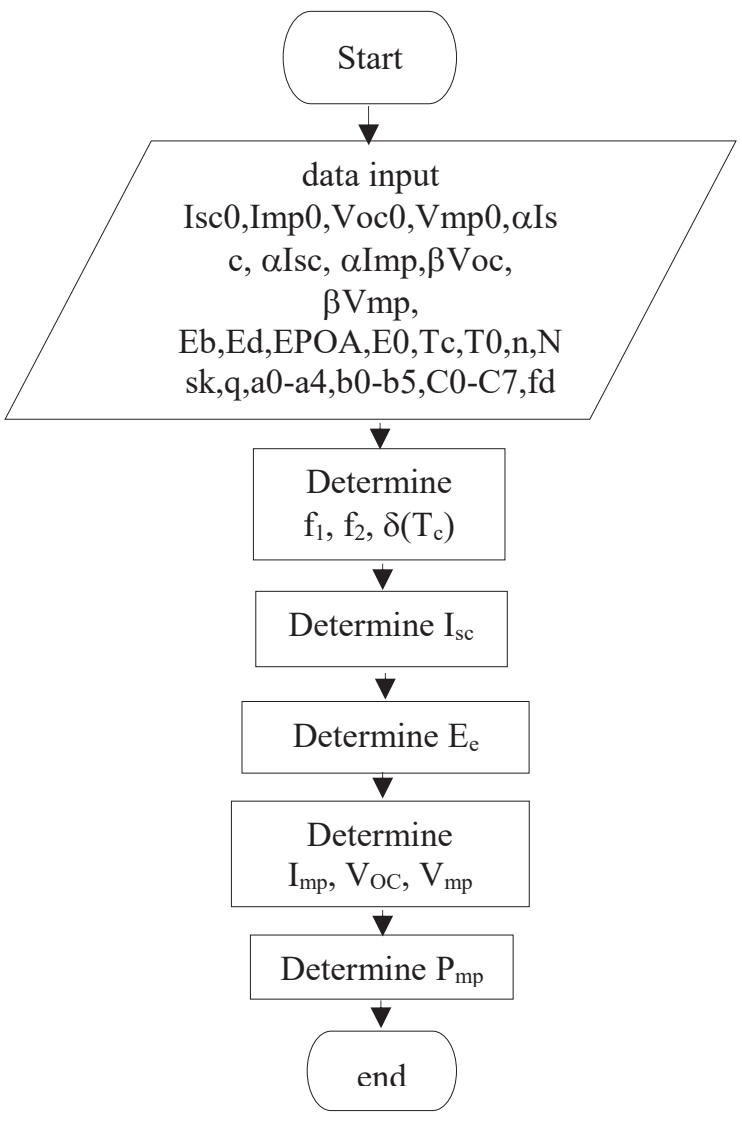

Fig. 3. PAPM calculation procedure

\subsubsection{Five Parameter Performance Model}

Five Parameter Performance Model (FPPM) is a method that is also used to calculate the performance of solar panels. This model was developed by W.De Soto et al [20]. Unlike the SPAPM model, FPPM requires fewer data in its calculations. The required data are the initial parameter values found in nameplate solar panels $I_{\mathrm{sc} 0}$,
$\mathrm{V}_{\mathrm{oc} 0}, \mathrm{I}_{\mathrm{mp} 0}, \mathrm{~V}_{\mathrm{mp} 0}$ and climatological data in the form of total solar radiation and ambient temperature and the curve of solar panel characteristics at STC. The FPPM method modeled a solar panel into a single diode equivalent circuit shown in Fig.4.

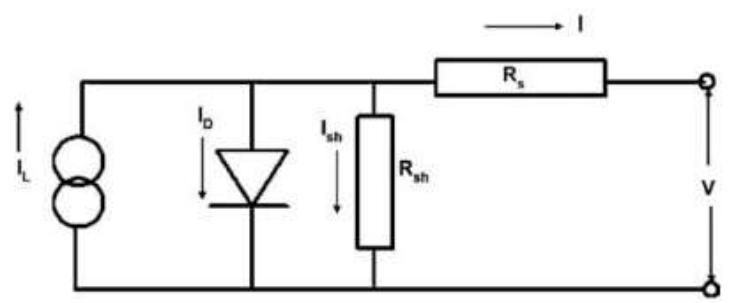

Fig. 4. Equivalent circuit representing the FPPM [20]

Based on Kirchoff's current law the following equations are obtained:

$I=I_{L}-I_{D}-I_{S h}$

$I=I_{L}-I_{0}\left[e^{\frac{V+I R s}{a}}-1\right]-\frac{V+I R_{S}}{R_{S h}}$

where

$a=\frac{N_{s} \cdot n \cdot k \cdot T_{C}}{q}$

The equivalent circuit in Fig. 2 shows the relation of voltage and current at the temperature of the cell and the constant solar radiation expressed in equation (32). In that equation five parameters must be known to determine current and voltage and also the power to the load, the five parameters are $\mathrm{I}_{\mathrm{L}}$ (Light Current), Diode Reverse Saturation Current, $\mathrm{R}_{\mathrm{s}}$ (Series Resistance), and $\mathrm{R}_{\text {sh }}$ (Shunt Resistance) and a (Diode Ideality Factor) are shown in equation (33). To obtain the value of the five parameters in equation 32, five parameters of the solar panel are required in the $\mathrm{STC}$ condition, ie short-circuit current $\left(\mathrm{I}_{\mathrm{sc}}\right)$, open circuit voltage $\left(\mathrm{V}_{\mathrm{oc}}\right), \mathrm{I}_{\mathrm{mp}}$ and $\mathrm{V}_{\mathrm{mp}}$ i.e current and voltage at maximum power $\left(\mathrm{P}_{\mathrm{mp}}\right)$ as it appears on the nameplate solar panel [20].

The five parameters found in equation (32) correspond to the operating conditions of the STC: $\mathrm{I}_{\mathrm{L}}$, ref, $\mathrm{I}_{0, \text { ref, }} \mathrm{a}_{\text {ref, }}, \mathrm{R}_{\mathrm{s}}$ ref, and $R_{\text {sh,ref. To determine these five reference }}$ parameters, three known conditions on the I-V characteristic curve of the STC substituted into equation (32) are:

1. For short circuit current: $I=I_{\mathrm{sc}, \text { ref }} ; \mathrm{V}=0$

$$
I_{s c 0}=I_{L, \text { ref }}-I_{0, \text { ref }}\left[e^{\frac{I_{s c, r e f} R_{s, r e f}}{a_{r e f}}}-1\right]-\frac{I_{s c, \text { ref }} R_{s, r e f}}{R_{s h, r e f}}
$$

2. For open circuit voltage: $I=0 ; V=V_{\text {oc, ref }}$

$$
0=I_{L, \text { ref }}-I_{0, \text { ref }}\left[e^{\frac{V_{o c, r e f}}{a_{\text {ref }}}}-1\right]-\frac{V_{o c, \text { ref }}}{R_{\text {sh, ref }}}
$$

3. For maximum power point $I=I_{m p, r e f} ; V=V_{m p, r e f}$

$$
\begin{gathered}
I_{m p 0}=I_{L, r e f}-I_{0, r e f}\left[e^{\frac{V_{m p, r e f}+I_{m p, r e f R} R, r e f}{a_{r e f}}}-1\right]- \\
\frac{V_{m p, r e f}+I_{m p, r e f} R_{s, r e f}}{R_{s h, r e f}}
\end{gathered}
$$


at the maximum condition the power derivative of the voltage is zero, then:

$$
\begin{aligned}
& \left.\frac{d(I V)}{d V}\right|_{m p}=0 \\
& \frac{d I}{d V}=-\frac{1}{R_{\text {sh }, \text { ref }}}
\end{aligned}
$$

and for $\mathrm{a}_{\mathrm{ref}}$ values can be determined by the equation:

$$
a_{r e f}=\frac{n \cdot N_{S} \cdot k \cdot T_{o}}{q}
$$

Thus, to determine the value of five parameters under operating conditions can be seen in the following flowchart:

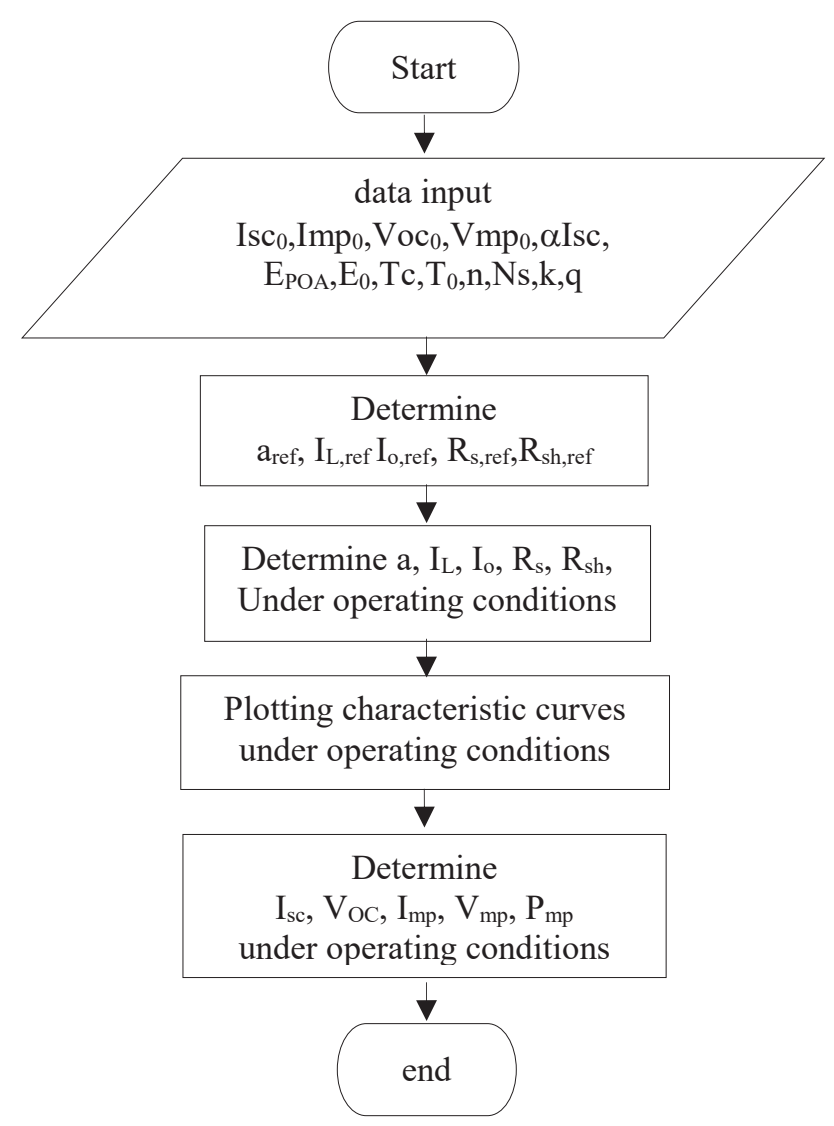

Fig. 5. Five paremeters calculation procedure

\section{Results and Discussion}

\subsection{Climatology data process}

Climatological data in table 1 is used to obtain the values of $\mathrm{B}$, EoT, $\mathrm{T}_{\text {Solar }}, \delta$ and $\theta_{\mathrm{hr}}$ with measurement day (d) is the 296th substituted to equation (2) then the value of B is $212,05^{\circ}$. This value is then fed to equation (1) so that Equation of Time (EoT) 16,05. Solar Time $\left(\mathrm{T}_{\text {solar }}\right)$ is calculated using the equation (3) with the selected local time i.e. 12 noon then the value of the $\mathrm{T}_{\text {solar }}$ is 12,14 and the hour angle $\left(\theta_{\mathrm{hr}}\right)$ is $2,114^{\circ}$ calculated using equation
(4). The amount of declination angle on the 296th day of $-12.19^{\circ}$ is calculated using equation (5).

Next is to determine the magnitude of zenith angle $\left(\theta_{z}\right)$ with local latitude equal to $-6,25$ (table 1), based on equation (8) than $\theta_{z}$ is $6,298^{\circ}$. This zenith angle value is used to determine $\mu_{\mathrm{s}}$ or sun azimuth angle, based on equation (9) the value of $\mu_{\mathrm{s}}$ is $-2,079^{\circ}$.

Based on the zenith and azimuth angle, Angle of Incidence (AOI), Air Mass (AM) dan Air Mas Absolut $\left(\mathrm{AM}_{\mathrm{a}}\right)$ values can be calculated using equations respectively (10), (16) and (17). With the equation we get the value of AOI (38,71o), AM (1.006) and $\mathrm{AM}_{a}$ (1.0025). The next step is to determine the total value of solar radiation absorbed by the surface of the solar panel or Plane of Array Irradiance $\left(\mathrm{E}_{\mathrm{poa}}\right)$. However, to determine $E_{\text {poa }}$, we first determine the value of Beam Radiation $\left(E_{b}\right)$, Diffuse Radiation $\left(\mathrm{E}_{\mathrm{d}}\right)$ and Ground Reflected Radiation $\left(E_{g}\right)$ using equations (11), (12) and (13). From the three equations $\mathrm{E}_{\mathrm{b}}\left(74,13 \mathrm{~W} / \mathrm{m}^{2}\right), \mathrm{E}_{\mathrm{d}}\left(360,2 \mathrm{~W} / \mathrm{m}^{2}\right)$, dan $\mathrm{E}_{\mathrm{g}}$ $\left(15,11 \mathrm{~W} / \mathrm{m}^{2}\right)$. Based on these values, the magnitude of Plane of Array Irradiance $\left(\mathrm{E}_{\mathrm{poa}}\right)$ shown in equation (15) are :

$$
E_{P O A}=74,13+360,2+15,11=449,45 \mathrm{~W} / \mathrm{m}^{2}
$$

The final part of this calculation is to determine the temperature of the module $\left(\mathrm{T}_{\mathrm{m}}\right)$ and cell temperature $\left(\mathrm{T}_{\mathrm{c}}\right)$. $T_{m}$ and $T_{c}$ are determined based on the material configuration and the type of mounting of the associated solar panels values of coefficients $\mathrm{a}, \mathrm{b}$ and $\Delta \mathrm{T}$. In this study using three types of solar panels are polycrystalline, monocrystalline, and thin film. The related information specifications of the three types of solar panels as well as the coefficients $\mathrm{a}, \mathrm{b}$ and $\Delta \mathrm{T}$ are presented in table 2 and table 3. The calculations of $\mathrm{T}_{\mathrm{m}}$ dan $\mathrm{T}_{\mathrm{c}}$ are done using equations (19) and (20), as for the values are as follows:

$$
\begin{gathered}
T_{m}=449,45 e^{(-3,56+(0.075 .7 .4))}+30.6=37,94^{\circ} \\
T_{c}=37,94^{\circ}+\frac{449,45}{1000} 3=39,28^{\circ}
\end{gathered}
$$

$\mathrm{T}_{\mathrm{m}}$ and $\mathrm{T}_{\mathrm{c}}$ in this study are considered the same for all three types of solar panels because they have the same material configuration and mounting type.

\subsection{Calculation process of SPAPM}

The SPAPM calculation process is done based on the flowchart shown in Figure 3. The data used are solar electrical specification data and the results of data processing climatology.

Calculations will be made on solar panels with the type of monocrystalline, but the results of the three types of solar panels will be displayed.

The first step of this process is to do the calculation of fl that is the value of Air Mass Modifier $\left(\mathrm{M}_{\mathrm{AM}}\right)$ using equation (18) and produce $f_{1}(A M a)$ is 0.982 . While $f_{2}$ is the value of the Angle of Incidence Modifier $\left(\mathrm{M}_{\mathrm{AOI}}\right)$ and the calculation uses the equation:

$$
\begin{aligned}
M_{A O I}= & b_{0}+b_{1} A O I+b_{2} A O I^{2}+b_{3} A O I^{3}+b_{4} A O I^{4}+ \\
& b_{5} A O I^{5}
\end{aligned}
$$

Based on equation (40) then the value of $f_{2}(A O I)$ is 0.9818 . Next, determine the value of thermal voltage

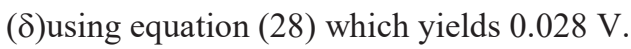


Equation (21) is used to determine the value of $\mathrm{I}_{\mathrm{sc}}$ under its operating conditions. This $\mathrm{I}_{\mathrm{sc}}$ value is influenced by the level of solar radiation absorbed by the solar panel. Through the equation (21) the resulting $I_{\mathrm{sc}}$ value is 1.87 A. The next is to determine the effective radiation value $\left(E_{e}\right)$, this value is determined by the ratio of the short circuit current value at the operating condition and at the STC condition. Based on equation (27) the value of $E_{e}$ produced is 0.425 (unitless)

$\mathrm{I}_{\mathrm{mp}}, \mathrm{V}_{\mathrm{oc}}$, and $\mathrm{V}_{\mathrm{mp}}$ under operating conditions are determined using equations (22), (23) and (24). The coefficient contained in the equation can be seen in Table 2. The resulting Imp value is $1.67 \mathrm{~A}$, Voc is $39.05 \mathrm{~V}$ and Vmp $32.44 \mathrm{~V}$. Based on the value of Imp and Vmp determined the value of $\mathrm{P}_{\mathrm{mp}}$ based on equation (25):

$$
P_{m p}=1,67.32,44=54,36 \mathrm{Wdc}
$$

The results of the calculations for the three types of solar panels using SPAPM are shown in the table below:

Table 4. Parameters output of each type of PV using SPAPM

\begin{tabular}{|l|c|c|c|c|c|}
\hline \multicolumn{1}{|c|}{ Type of PV } & $\begin{array}{c}\mathrm{I}_{\mathrm{sc}} \\
(\mathrm{A})\end{array}$ & $\begin{array}{c}\mathrm{V}_{\mathrm{oc}} \\
(\mathrm{V})\end{array}$ & $\begin{array}{c}\mathrm{I}_{\mathrm{mp}} \\
(\mathrm{A})\end{array}$ & $\begin{array}{c}\mathrm{V}_{\mathrm{mp}} \\
(\mathrm{V})\end{array}$ & $\begin{array}{c}\mathrm{P}_{\mathrm{mp}} \\
(\mathrm{Wdc})\end{array}$ \\
\hline $\begin{array}{l}\text { Monocrystaline } \\
\text { (Siemens SP-75) }\end{array}$ & 1,87 & 39,05 & 1,67 & 32,44 & 54,36 \\
\hline $\begin{array}{l}\text { Polycrystaline } \\
\text { (Solarex MSX-64) }\end{array}$ & 1,83 & 37,62 & 1,65 & 31,25 & 51,57 \\
\hline $\begin{array}{l}\text { Thinfilm } \\
\text { (AstropowerAPX- } \\
\text { 90) }\end{array}$ & 2,22 & 26,02 & 1,89 & 20,98 & 39,62 \\
\hline
\end{tabular}

\subsection{Calculation process of FPPM}

Calculation of the performance of solar panels using FPPM is done following the flowchart is shown in Figure 5. The data used are solar panel specification data on STC condition, total radiation absorbed by a solar panel, and cell temperature

The first step of the calculation is to determine the value of reference or $\mathrm{a}_{\mathrm{ref}}$ ideality factor with equation (39). With the resulted equation $\mathrm{a}_{\mathrm{ref}}$ is $1.898 \mathrm{eV}$. Next is to determine $\mathrm{R}_{\mathrm{s} \text {, ref }}$ using equation (41):

$$
R_{s, r e f}=-M \frac{I_{s c o}}{I_{m p o}}+\frac{V_{m p o}}{I_{m p o}}\left(1-\frac{I_{s c o}}{I_{m p o}}\right)
$$

The value of $\mathrm{M}$ is the slope of the $\mathrm{V}_{\mathrm{oc}}$ on the characteristic curve calculated using equation (42):

$M=\frac{V_{o c 0}}{I_{s c 0}}\left(k_{1} \frac{I_{m p 0} V_{m p 0}}{I_{s c 0} V_{o c 0}}+k_{2} \frac{V_{m p 0}}{V_{o c 0}}+k_{3} \frac{I_{m p 0}}{I_{s c 0}}+k_{4}\right)$

while the $\mathrm{k} 1 \mathrm{k} 2 \mathrm{k} 3$ and $\mathrm{k} 4$ are:

$k=\left(\begin{array}{c}-5,411 \\ 6,450 \\ 3,41 \\ -4,422\end{array}\right)$

In some cases the value of $R_{s, \text { ref }}$ produced by equation (41) is sometimes negative. This problem is solved by removing $R_{s}$ and $R_{s h}$ components in equivalent circuits and replacing them with photovoltaic resistance or $R_{p v}$
[29]. Thus the single diode equivalent circuit in figure. 4 becomes:

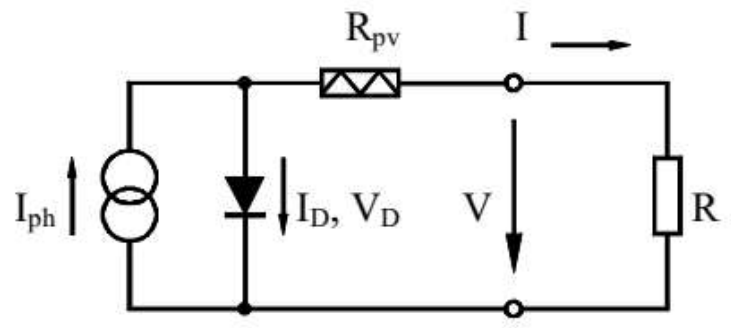

Fig. 6. Equivalent circuit diagram for the effective solar cell characteristic [29]

The equation model generated according to the equivalent circuit in Fig. 6 is:

$$
I=I_{p h}-I_{0}\left(e^{\frac{V+I_{R p v}}{V_{T}}}\right)
$$

$V=V_{T} \ln \frac{I_{p h}-I+I_{0}}{I_{0}}-I R_{p v}$

Based on equations (44) and (45) by substituting the working conditions obtained from the characteristic curve of the equation, we obtain the values of $\mathrm{V}_{\mathrm{T}}, \mathrm{I}_{0}$, and $\mathrm{I}_{\mathrm{ph}}$, which are:

$$
\begin{aligned}
& V_{T}=-\left(M+R_{p v}\right) I_{s c} \\
& I_{0}=I_{s c} e^{\frac{V o c}{V_{T}}} \\
& I_{p h}=I_{s c}
\end{aligned}
$$

The determination of the value of $R_{s}$ requires the value of the second parameter resulting from the total radiation different from the fixed cell temperature, resulting in the value of the equation:

$R_{S}=\frac{V_{2}-V_{1}}{I_{s c 1}-I_{S c 2}}$

The values of $V_{1}$ and $V_{2}$ are given by equation (45), while $\mathrm{V}_{1}$ and $\mathrm{V}_{2}$ are:

$V_{1}=V\left(I_{s c 1}-\Delta I, R_{p v 1}, V_{T 1}, I_{01}, I_{p h 1}\right)$

$V_{2}=V\left(I_{s c 2}-\Delta I, R_{p v 2}, V_{T 2}, I_{02}, I_{p h 2}\right)$

Index 2 represents a parameter with a characteristic value with a lower short-circuit current. The value of I is determined by the equation:

$I_{n}=I_{s c n}-\Delta I$

with

$\Delta I=0,5 \times I_{s c 2}$

Determination of $\mathrm{R}_{\mathrm{s} \text {,ref }}$ value on solar panel with monocrystalline type (table 2) using equation (41), because it does not produce a negative value. The value of $R_{s, \text { ref }}$ is determined by first determining the value of $M$ in equation (42): 


$$
\begin{aligned}
& M=\frac{42,93}{4,37}\left(-5,411 \frac{(3,96)(33,68)}{(4,37)(42,93)}+6,45 \frac{33,68}{42,93}\right. \\
& \left.+3,417 \frac{3,96}{4,37}-4,422\right) \\
& M=-1,102
\end{aligned}
$$

So the value of $\mathrm{R}_{\mathrm{s}, \mathrm{ref}}$

$$
R_{s, r e f}=-(-1,102) \frac{4,37}{3,96}+\frac{33,68}{3,96}\left(1-\frac{4,37}{3,96}\right)=0,335 \Omega
$$

The next step after the known value of $a_{\text {ref }}$, and $R_{s, r e f}$ is to determine the value of $I_{L, \text { ref, }} I_{0, \text { ref, }}$ and $R_{\text {sh,ref. }}$ To determine $I_{L, \text { ref }}$ the equation (35) can be written as:

$$
I_{L, \text { ref }}=I_{0, \text { ref }}\left[e^{\frac{V_{o c, r e f}}{a_{\text {ref }}}}-1\right]+\frac{V_{o c, \text { ref }}}{R_{\text {sh, ref }}}
$$

Equation (54) is substituted into equations (34) and (36), resulting in the equation:

$$
\begin{aligned}
& I_{s c 0}=I_{0, r e f}\left[e^{\frac{V_{o c o}}{a_{r e f}}}-e^{\frac{I_{s c o} R_{s, r e f}}{a_{r e f}}}\right]+\frac{V_{o c o} V_{m p o}-I_{m p o} R_{s, r e f}}{R_{s h, r e f}} \\
& I_{m p 0}=I_{0, r e f}\left[e^{\frac{V_{o c o}}{a_{r e f}}}-e^{\frac{V_{m p o}+I_{m p o} R s, r e f}{a_{r e f}}}\right]+\frac{V_{o c o}-V_{m p o}-I_{m p o} R_{s, r e f}}{R_{s h, r e f}}
\end{aligned}
$$

From equation (55) and (56) two unknowns are $\mathrm{I}_{0, \text { ref }}$

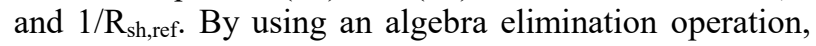
one of the unknown variables can be eliminated so that other variables can be determined. In this case the eliminated variables are $1 / \mathrm{R}_{\mathrm{sh}, \mathrm{ref}}$ so it can be determined by $\mathrm{I}_{\text {oref: }}$

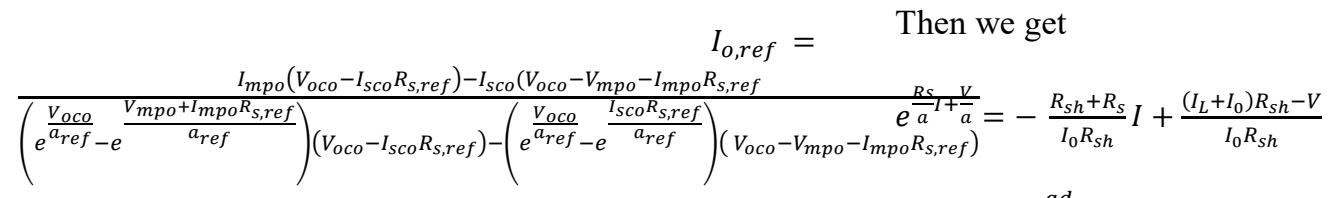

$$
\begin{aligned}
& -t=a x+\frac{a d}{c}
\end{aligned}
$$

From equation (57),(58) and (59) we obtained :

$$
\begin{gathered}
I_{L}=1,97 \mathrm{~A} \\
I_{0}=4,75 \times 10^{-9} \mathrm{~A} \\
R_{\text {sh }}=213,62 \Omega
\end{gathered}
$$

The five parameters are then substituted into equation (32) so that in obtaining the current equation is:

$$
I=1,97-4,75 \times 10^{-9}\left[e^{\frac{V+0,341}{1,98}}-1\right]-\frac{V+0,341}{213,62}
$$

Equation (60) is used to plot the characteristic curve (I-V) of the solar panel under its operating conditions.

\subsection{Characteristic Curve on Operating Conditions}

Equation (60) is used to plot the characteristic curve (IV). But it cannot be directly used to plot characteristic curves. It is known that the current can be indicated as a function of the voltage I = I (V) by the Lambert's W transcendental function [30]. Lambert's W function is a $\mathrm{W}(\mathrm{x})$ solution of the equation $x=W(x) e^{[W(x)]}$. Using this function equation (32) to form $\mathrm{I}=\mathrm{I}(\mathrm{V})$. The initial step of equation (32) is changed to:

$$
I^{a x+b}=C x+d
$$

By equation (57) the value of $\mathrm{I}_{0, \text { ref: }}$

$$
I_{o, \text { ref }}=5,92 \times 10^{-10} \mathrm{~A}
$$

As for $\mathrm{R}_{\text {sh, ref }}$ is determined by using equation (56) and its value is

and

$$
R_{\text {sh,ref }}=96,01 \Omega
$$

$$
I_{L, r e f}=4,38 \mathrm{~A}
$$

$\mathrm{I}_{\mathrm{L}, \text { ref }}$ is determined by using equation (54).

After all parameters in the reference condition (STC) is known then the next step is to determine the value of the five parameters of the solar panel under its operating conditions.

The five parameters are ideality factor (a), this value depends on the cell temperature of the module. The value of a is determined by using equation (33):

$$
a=1,989 \mathrm{eV}
$$

Subsequently determined $\mathrm{I}_{\mathrm{L}}, \mathrm{I}_{\mathrm{o}}$, and $\mathrm{R}_{\text {sh }}, \mathrm{I}_{\mathrm{L}}$ values are influenced by total radiation and cell temperature, $I_{o}$ is
Substituting equation (61) into (63) so that it is produced:

$$
\begin{gathered}
p^{-t-\frac{a d}{c}} p^{b}=c\left(\frac{-t-\frac{a d}{c}}{a}\right)+d \\
p^{-t} p^{b-\frac{a d}{c}}=\frac{-t c}{a} \\
p^{t}=-\frac{a}{t c} p^{b-\frac{a d}{c}} \\
t p^{t}=-\frac{a}{c} p^{b-\frac{a d}{c}}
\end{gathered}
$$

then $\mathrm{p}^{\mathrm{t}}$ in equation (64) is changed by exponential form:

$$
t e^{t \ln p}=-\frac{a}{t c}(\ln p) p^{b-\frac{a d}{c}}
$$

Using the definition of Lambert's $\mathrm{W}$ function, then the equation 65 can be converted to $x=W(y)$ then in the equation: 


$$
t \ln p=W\left(-\frac{a}{t c}(\ln p) p^{b-\frac{a d}{c}}\right)
$$

Next substitute equation (63) to equation (66), resulting in a solution in the form of Lambert's W function:

$$
x=-\frac{1}{a \ln p} W\left(-\frac{a \ln p}{c} p^{b-\frac{a d}{c}}\right)-\frac{d}{c}
$$

Thus, equation (62) can be converted to equation (67), then the equation $\mathrm{I}=\mathrm{I}(\mathrm{V})$ is:

$$
I=\frac{R_{s h}}{R_{s h}+R_{S}}\left(I_{L}+I_{0}\right)-\frac{V}{R_{s h}+R_{S}}-\frac{a}{R_{S}} W(\theta)
$$

where

$$
\left.\theta=\frac{R_{S} I_{0}}{a} \frac{R_{S h} I_{0}}{R_{S h}+R_{S}} e^{\left(\frac{R_{S h} R_{S}\left(I_{L}+I_{0}\right)+V}{R_{S h}+R_{S}} a\right.}\right)
$$

\begin{tabular}{|c|c|c|c|c|}
\hline $\begin{array}{c}\text { V } \\
\text { (Volt) }\end{array}$ & $\theta$ (Volt) & $\mathrm{W}(\theta)$ & $\mathrm{I}(\mathrm{A})$ & $\mathrm{P}(\mathrm{Wdc})$ \\
\hline 0 & $1,116 \mathrm{E}-09$ & 0 & 1,9704 & 0 \\
\hline 1 & $1,843 \mathrm{E}-09$ & 0 & 1,9657 & 1,9657 \\
\hline 2 & $3,045 \mathrm{E}-09$ & 0 & 1,9610 & 3,9221 \\
\hline 3 & 5,03E-09 & 0 & 1,9564 & 5,8692 \\
\hline 4 & $8,309 \mathrm{E}-09$ & 0 & 1,9517 & 7,8069 \\
\hline 5 & $1,373 \mathrm{E}-08$ & 0 & 1,9470 & 9,7352 \\
\hline 6 & $2,268 \mathrm{E}-08$ & 0 & 1,9423 & 11,6543 \\
\hline 7 & $3,746 \mathrm{E}-08$ & 0 & 1,9377 & 13,5639 \\
\hline 8 & $6,189 \mathrm{E}-08$ & 0 & 1,9330 & 15,4642 \\
\hline 9 & $1,022 \mathrm{E}-07$ & 0 & 1,9283 & 17,3552 \\
\hline 10 & $1,689 \mathrm{E}-07$ & 0 & 1,9236 & 19,2368 \\
\hline 11 & $2,79 \mathrm{E}-07$ & 0 & 1,9190 & 21,1091 \\
\hline 12 & $4,61 \mathrm{E}-07$ & 0 & 1,9143 & 22,9720 \\
\hline 13 & $7,616 \mathrm{E}-07$ & 0,000001 & 1,9096 & 24,8255 \\
\hline 14 & $1,258 \mathrm{E}-06$ & 0,000001 & 1,9049 & 26,6698 \\
\hline 15 & $2,078 \mathrm{E}-06$ & 0,000002 & 1,9003 & 28,5046 \\
\hline 16 & $3,434 \mathrm{E}-06$ & 0,000003 & 1,8956 & 30,330 \\
\hline 17 & $5,672 \mathrm{E}-06$ & 0,000006 & 1,8909 & 32,1459 \\
\hline 18 & $9,371 \mathrm{E}-06$ & 0,000009 & 1,8862 & 33,9523 \\
\hline 19 & $1,548 \mathrm{E}-05$ & 0,000015 & 1,8815 & 35,7491 \\
\hline 20 & $2,557 \mathrm{E}-05$ & 0,000026 & 1,8767 & 37,5359 \\
\hline 21 & $4,225 \mathrm{E}-05$ & 0,000042 & 1,8720 & 39,3125 \\
\hline 22 & $6,98 \mathrm{E}-05$ & 0,00007 & 1,8671 & 41,0780 \\
\hline 23 & 0,0001153 & 0,000115 & 1,8622 & 42,8316 \\
\hline 24 & 0,0001905 & 0,00019 & 1,8571 & 44,5710 \\
\hline 25 & 0,0003147 & 0,000315 & 1,8517 & 46,2928 \\
\hline 26 & 0,0005199 & 0,00052 & 1,8458 & 47,9914 \\
\hline 27 & 0,0008588 & 0,000858 & 1,8391 & 49,6569 \\
\hline 28 & 0,0014188 & 0,001417 & 1,8311 & 51,2724 \\
\hline 29 & 0,0023439 & 0,002338 & 1,8210 & 52,8097 \\
\hline 30 & 0,0038722 & 0,003857 & 1,8073 & 54,2203 \\
\hline 31 & 0,0063969 & 0,006356 & 1,7878 & 55,4235 \\
\hline 32 & 0,0105678 & 0,010458 & 1,7588 & 56,2837 \\
\hline 33 & 0,0174582 & 0,017161 & 1,7144 & 56,5771 \\
\hline 34 & 0,0288413 & 0,028044 & 1,6452 & 55,9392 \\
\hline 35 & 0,0476464 & 0,045526 & 1,5369 & 53,7937 \\
\hline 36 & 0,0787128 & 0,07316 & 1,3684 & 49,2652 \\
\hline 37 & 0,1300351 & 0,115814 & 1,1109 & 41,1053 \\
\hline 38 & 0,2148204 & 0,179519 & 0,7286 & 27,6883 \\
\hline 39 & 0,3548874 & 0,270719 & 0,1833 & 7,1502 \\
\hline 39,1 & 0,3731574 & 0,281581 & 0,1184 & 4,6326 \\
\hline 39,2 & 0,392368 & 0,29278 & 0,0516 & 2,0238 \\
\hline
\end{tabular}

Table 5. The current value for each voltage value with function Lambert's W
The values of the five parameters under operating conditions are substituted into equations (68) and (69) resulting in the value of the current of each voltage of the solar panel. Equation (69) cannot be directly substituted into (68), but it must be entered into Lambert's W function calculator to determine the value of the function $\mathrm{W}(\theta)$. This value is inputed into the current calculation in equation 68.

Based on the calculation in Table 5, the curve of I-V under operating conditions is shown in the following figure:

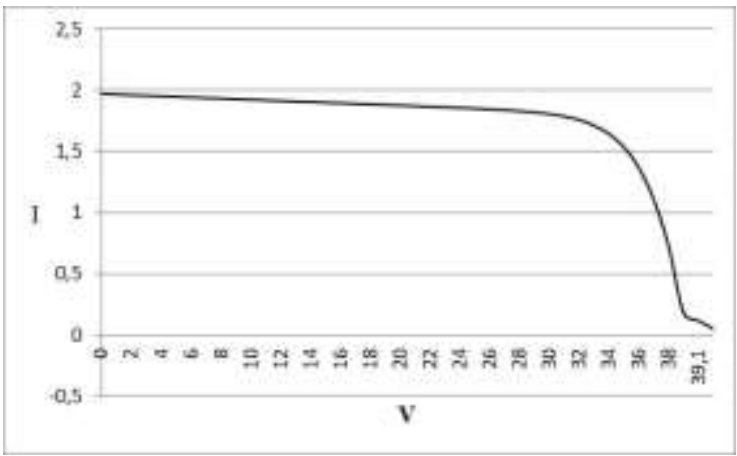

Fig. 7. I-V Curve of Solar Panel under Operating Condition

In the calculation of solar panel performance with five parameters method, the value of solar panel output parameters can be known from the calculation of the current for each voltage value and characteristic curve. The calculation results for the three types of solar panels using five parameters are shown in the table below:

Table 6. Parameters output of each type of PV using FPPM

\begin{tabular}{|l|c|c|c|c|c|}
\hline \multicolumn{1}{|c|}{ Type of PV } & $\begin{array}{c}\mathrm{I}_{\mathrm{sc}} \\
(\mathrm{A})\end{array}$ & $\begin{array}{c}\mathrm{V}_{\mathrm{oc}} \\
(\mathrm{V})\end{array}$ & $\begin{array}{c}\mathrm{I}_{\mathrm{mp}} \\
(\mathrm{A})\end{array}$ & $\begin{array}{c}\mathrm{V}_{\mathrm{mp}} \\
(\mathrm{V})\end{array}$ & $\begin{array}{c}\mathrm{P}_{\mathrm{mp}} \\
(\mathrm{Wdc})\end{array}$ \\
\hline $\begin{array}{l}\text { Monocrystaline } \\
\text { (Siemens SP-75) }\end{array}$ & 1,97 & 39,27 & 1,72 & 32,9 & 56,58 \\
\hline $\begin{array}{l}\text { Polycrystaline } \\
\text { (Solarex MSX-64) }\end{array}$ & 1,91 & 37,71 & 1,65 & 31,91 & 52,57 \\
\hline $\begin{array}{l}\text { Thinfilm } \\
\text { (AstropowerAPX- } \\
\text { 90) }\end{array}$ & 2,29 & 26,08 & 2,17 & 19,98 & 43,29 \\
\hline
\end{tabular}

\section{Conclusion}

In this research, performance assessment with SPAPM method, in monocrystalline type solar panels yielded a larger $\mathrm{P}_{\mathrm{mp}}$ value of $54.36 \mathrm{Wdc}$, and in second and third order of Polycrystalline $51.57 \mathrm{Wdc}$, Thinfilm was 39.62 $\mathrm{Wdc}$. The same thing is produced by FPPM method where Monocrystalline type solar panel produces larger $\mathrm{P}_{\mathrm{mp}}$ which is $56.58 \mathrm{Wdc}$ and followed by Polycrystalline 52.7 Wdc and Thinfilm 43.29 Wdc. The results of the calculations of both methods show that for the three types of solar panels used, the FPPM method yields a larger $\mathrm{P}_{\mathrm{mp}}$ value than the SPAPM method. This is because the calculation using SPAPM method is much influenced by the climatological conditions, while the FPPM method is only influenced by the total radiation and cell temperature. Nevertheless the Pmp value generated by 
FPPM method for the three types of solar panels is close to the Pmp value generated by the SPAPM method.

The results of this study show that FPPM method is more efficient and optimal in assessing the performance of solar panel compared with SPAPM method. This occurs because the FPPM method requires only a small amount of data but can provide the results of solar panel output parameters that approximate the results obtained by the PAPM method. In addition to these two methods, solar panels with thin film types have smaller $\mathrm{P}_{\mathrm{mp}}$ values of $39.62 \mathrm{~W}$ (SPAPM) and 43.29 (FPPM), this occurs because theoretically thin film has a smaller efficiency than the other two types.

The Authors would like to thank this work supported by "Hibah Penelitian Kerjasama Antar Perguruan Tinggi" Kemenristek Dikti. The Authors would like to thank for all member in Tropical Renewable Energy Centre (TREC) Universitas Indonesia.

\section{Reference}

1. Bloomberg, "Global Trends in Renewable Energy Investment 2016," p. 84.

2. O. O. Ogbomo, E. H. Amalu, N. N. Ekere, and P. O. Olagbegi, "A review of photovoltaic module technologies for increased performance in tropical climate," Renew. Sustain. Energy Rev., vol. 75, pp. 1225-1238, 2017.

3. M. Schweiger, W. Herrmann, A. Gerber, and U. Rau, "Understanding the energy yield of photovoltaic modules in different climates by linear performance loss analysis of the module performance ratio," IET Renew. Power Gener., vol. 11, no. 5, pp. 558-565, 2017.

4. S. Guha, J. Y. United, and S. Ovonic, "HighEfficiency Amorphous Silicon Alloy Based Solar Cells and Modules Final Technical Progress Report High-Efficiency Amorphous Silicon Alloy Based Solar Cells and Modules Final Technical Progress Report," no. October, 2005.

5. B. D. Tsai, Y. T. Hsu, T. T. Lin, L. M. Fu, C. H. Tsai, and J. C. Leong, "Performance of an INER HCPV module in NPUST," Energy Procedia, vol. 14, pp. 893-898, 2012.

6. T. Dierauf, A. Growitz, S. Kurtz, and C. Hansen, "Weather-Corrected Performance Ratio Technical Report NREL/TP-5200-57991," 2013.

7. E. Skoplaki and J. A. Palyvos, "On the temperature dependence of photovoltaic module electrical performance: A review of efficiency/power correlations," Sol. Energy, vol. 83, no. 5, pp. 614624, 2009.

8. S. Dubey, J. N. Sarvaiya, and B. Seshadri, "Temperature dependent photovoltaic (PV) efficiency and its effect on PV production in the world - A review," Energy Procedia, vol. 33, pp. 311-321, 2013.

9. E. Skoplaki and J. A. Palyvos, "Operating temperature of photovoltaic modules : A survey of pertinent correlations," vol. 34, pp. 23-29, 2009.

10. O. M. Eludoyin, I. O. Adelekan, R. Webster, and A. O. Eludoyin, "Air temperature, relative humidity, climate regionalization and thermal comfort of Nigeria," vol. 2018, no. October 2013, pp. 2000-2018, 2018.

11. C. U. Ike, "The Effect of Temperature on the Performance of A Photovoltaic Solar System In Eastern Nigeria," vol. 3, no. 12, pp. 10-14, 2013.

12. S. Mekhilef, R. Saidur, and M. Kamalisarvestani, "Effect of dust, humidity and air velocity on efficiency of photovoltaic cells," Renew. Sustain. Energy Rev., vol. 16, no. 5, pp. 2920-2925, 2012.

13. A. Ndiaye, C. M. F. Kébé, A. Charki, and V. Sambou, "Photovoltaic Platform for Investigating PV Module Degradation," Energy Procedia, vol. 74, pp. 1370-1380, 2015.

14. T. M. Walsh, Z. Xiong, and Y. Sheng, "Energy Procedia Singapore Modules - Optimised PV Modules for the Tropics," vol. 00, no. 2011, 2012.

15. John A. Duffie and William A. Beckman, "Solar Engineering of Thermal Processes.” New York: Wiley-Interscience Publication, 1980.

16. http://www.pveducation.org/pvcdrom/2-propertiessunlight/solar-time, "Solar Time | PVEducation." 2108.

17. Http://www.pveducation.org/pvcdrom/propertiesof-sunlight/declination-angle, "Declination Angle PVEducation." 2018.

18. Http://www.pveducation.org/pvcdrom/propertiesof-sunlight/elevation-angle, "Elevation Angle PVEducation." 2018.

19. http://www.pveducation.org/pvedrom/propertiesof-sunlight/azimuth-angle, "Azimuth Angle PVEducation." 2018.

20. W. De Soto, S. A. Klein, and W. A. Beckman, "Improvement and validation of a model for photovoltaic array performance," vol. 80, pp. 78$88,2005$.

21. https://pvpmc.sandia.gov/modeling-steps/1weather-design-inputs/plane-of-array-poairradiance/calculating-poa-irradiance/poa-beam/, "PV Performance Modeling Collaborative POA Beam.” 2018.

22. https://pvpmc.sandia.gov/modeling-steps/1weather-design-inputs/plane-of-array-poairradiance/calculating-poa-irradiance/poa-skydiffuse/isotropic-sky-diffuse-model/, "PV Performance Modeling Collaborative Isotropic Sky Diffuse Model.” 2018.

23. https://pvpmc.sandia.gov/modeling-steps/1weather-design-inputs/plane-of-array-poairradiance/calculating-poa-irradiance/poa-groundreflected/, "PV Performance Modeling Collaborative POA Ground Reflected.” 2018.

24. https://pvpmc.sandia.gov/modeling-steps/1weather-design-inputs/plane-of-array-poairradiance/, "PV Performance Modeling 
Collaborative Plane of Array (POA) Irradiance." 2018.

25. http://www.pveducation.org/pvcdrom/propertiesof-sunlight/air-mass, "Air Mass PVEducation." 2018.

26. D.King J.Kratochvil and W.Boyson, "Measuring Solar Spectral and Angle-of-Incidence Effects on PV Modules and Solar Irradiance Sensors." Sandia National Laboratories, 1997.

27. D. L. King, W. E. Boyson, and J. A. Kratochvil, "PHOTOVOLTAIC ARRAY PERFORMANCE MODEL," no. November, 2003.

28. https://pvpmc. sandia.gov/modeling-steps/2-dcmodule-iv/module-temperature/sandia-moduletemperature-model/, "PV Performance Modeling Collaborative Sandia Module Temperature Model." 2018.

29. A. Wagner, "Peak-Power and Internal Series Resistance Measurement Under Natural Ambient Conditions," Proc. EuroSun 2000, pp. 1-7, 2000.

30. C. W. Hansen, "Parameter estimation for single diode models of photovoltaic modules," Sandia Rep., no. SAND2015-2065, pp. 1-68, 2015.

\begin{tabular}{|ll|}
\hline \multicolumn{2}{|l|}{ Nomenclature } \\
& \\
Eot & Equation of Time \\
$\mathrm{B}$ & Slope Angel in degree \\
$\mathrm{d}$ & the number of days since the start of the year \\
$\mathrm{T}_{\text {solar }}$ & Solar Time \\
$\mathrm{T}_{\text {local }}$ & Local Time \\
Long $_{\mathrm{sm}}$ & Longitude Standard Meridian \\
Long & Longitude Local \\
$\theta_{\mathrm{hr}}$ & Hour Angle \\
$\delta$ & Sun Declination Angle \\
$\mathrm{h}$ & Sun Elevation \\
$\varphi$ & Local Latitude \\
$\theta_{\mathrm{z}}$ & Zenith Angle \\
$\mu \mathrm{S}$ & Sun Azimuth Angle \\
$\mathrm{AOI}$ & Angle of Incidence $\left(\theta_{1}\right)$ \\
$\mathrm{M}_{\mathrm{AOI}}$ & Incidence Angle Modifier \\
$\mathrm{n}_{1}$ & Air refreksi index \\
$\mathrm{n}_{1}$ & Surface of Solar Panel Refraksi Index \\
$\theta_{2}$ & Refreksi Angle \\
$\tau_{\mathrm{r}}$ & Fresnel equation for non-reflected \\
& Unpolarized radiation \\
$\tau_{\mathrm{a}}$ & absorbed radiation \\
$\mathrm{K}$ & Constant Proportionality $\left(4 \mathrm{~m}^{-1}\right)$ \\
$\tau$ & Transmittance \\
$\mathrm{T}_{\mathrm{m}}$ & Module Temperature $\left({ }^{\circ} \mathrm{C}\right)$ \\
$\mathrm{T}_{\mathrm{c}}$ & Cell Temperature $\left({ }^{\circ} \mathrm{C}\right)$ \\
$\mathrm{T}_{\mathrm{a}}$ & Ambient Temperature $\left({ }^{\circ} \mathrm{C}\right)$ \\
$\mathrm{E}_{\mathrm{POA}}$ & Plane ofArray Irradiance $\left(\mathrm{W} / \mathrm{m}^{2}\right)$ \\
$\left.\mathrm{E}_{\mathrm{o}}\right)$ & Solar Radiation at STC $\left(1000 \mathrm{~W} / \mathrm{m}^{2}\right)$ \\
$\mathrm{W}_{\mathrm{s}}$ & Wind Speed (m/s) \\
& \\
\hline
\end{tabular}

\begin{tabular}{|ll|}
\hline $\mathrm{a}, \mathrm{b}$ & constanta \\
$\Delta \mathrm{T}$ & temperature difference between modul \\
& surface and back modul \\
$\mathrm{I}_{\mathrm{sc}}$ & Short Circuit Current (A) \\
$\mathrm{I}_{\mathrm{sc} 0}$ & Short Circuit Current at STC (A) \\
$\mathrm{I}_{\mathrm{mp}}$ & Maximum Current (A) \\
$\mathrm{I}_{\mathrm{mp} 0}$ & Maximum Current at STC (A) \\
$\mathrm{V}_{\mathrm{oc}}$ & Open Circuit Voltage (V) \\
$\mathrm{V}_{\mathrm{oc} 0}$ & Open Circuit Voltage at STC (V) \\
$\mathrm{V}_{\mathrm{mp}}$ & Maximum Voltage (V) \\
$\mathrm{V}_{\mathrm{mp} 0}$ & Maximum Voltage at STC \\
$\alpha_{\mathrm{Isc}}$ & Normalized Temperature Coefficient \\
& (\%o/ $\left.{ }^{\circ} \mathrm{C}\right)$ \\
$\alpha_{\mathrm{Imp}}$ & Normalized Temperature Coefficient of \\
& maximum power $\left(\% /{ }^{\circ} \mathrm{C}\right)$ \\
$\beta_{\mathrm{Voc}}$ & Coefficient Temperature of open circuit \\
& voltage $\left(\mathrm{V} /{ }^{\circ} \mathrm{C}\right)$ \\
$\beta_{\mathrm{Vmp}}$ & Coefficient Temperature of \\
$\mathrm{Pmp}$ & MaximumVoltage $\left(\mathrm{V} /{ }^{\circ} \mathrm{C}\right)$ \\
$\mathrm{FF}$ & Maximum Power $(\mathrm{W})$ \\
$\mathrm{k}$ & Fill Factor \\
$\mathrm{T}_{\mathrm{o}}$ & Boltzman Constanta $\left(1,38066 \times 10^{-23}\right)$ \\
\hline
\end{tabular}

